\section{Enhancing science-based conservation of the threatened flora of Sardinia}

The project Collection of Seeds of Native Plant Species from Sardinian Flora for Ex situ Conservation at the Millennium Seed Bank was successfully concluded in 2015. This collaborative project started in 2006 following the signing of a Memorandum of Collaboration between the Royal Botanic Gardens, Kew (RBG Kew) and the Centre for Conservation of Biodiversity (CCB) at the University of Cagliari, Italy. The aim of the project was to study and conserve native species of Sardinia within the framework of the Millennium Seed Bank Partnership led by RBG Kew. Sardinia is the second largest island in the Mediterranean Sea, with a vascular flora of c. 2,500 native species and a high level of endemism (c. 370 taxa). Since 1997 CCB has been playing an active role in conserving the island's plant diversity through its Sardinian Germplasm Bank. This role has been strengthened through this project by enhancing seed conservation, training and research activities on Sardinian and Mediterranean plant species.

As part of the conservation activities, seed lots of 218 native species were collected and stored at the Sardinian Germplasm Bank and duplicates sent to the Millennium Seed Bank at RBG Kew for back-up storage. About $40 \%$ of these species are endemic to the West Mediterranean region, with about half of these being exclusive to the island. About $15 \%$ of the stored species are included in The European Threatened Plant List (Sharrock \& Jones, 2009, Conserving Europe's Threatened Plants: Progress towards Target 8 of the Global Strategy for Plant Conservation, Botanic Gardens Conservation International). Seeds of eight of the top 10 most threatened Sardinian endemics (Bacchetta et al., 2012, Anales Jardin Botanico Madrid, 69, 81-89) have been conserved, including Critically Endangered species such as Lamyropsis microcephala and Polygala sinisica for which ex situ conservation measures had not been previously implemented.

Scientific and technical training on seed conservation has been delivered through annual exchange visits, four cosupervised $\mathrm{PhD}$ students (two with scholarships funded by Cagliari University and the EU), and a Kew Visiting Honorary Research Associate position. The research objectives were to (1) investigate seed biology and germination ecophysiology of threatened Sardinian species, (2) understand future challenges for plant survival, and (3) study plant demography and assess the impact of actual and potential threats on populations. The biological and environmental control of seed dormancy and germination were investigated through joint research on 11 species (Aquilegia barbaricina, A. cremnophila, A. nugorensis, Centranthus amazonum, C. ruber, Lamyropsis microcephala, Polygala sardoa, P. sinisica, Paeonia corsica, Rhamnus persicifolia and Ribes multiflorum subsp. sandalioticum). The impact of climate change on the seed dormancy loss and germination kinetics was modelled for A. barbaricina, P. corsica, $R$. multiflorum subsp. sandalioticum, $R$. persicifolia and Taxus baccata through seed germination experiments both in the laboratory and the field, and how thermal thresholds for dormancy loss and germination may vary along an altitudinal gradient has being investigated. In parallel, several plant population studies began for L. microcephala and Anchusa littorea, to facilitate a better understanding of plant conservation and management in situ.

This successful collaboration has contributed significantly towards Global Strategy for Plant Conservation Target 8 (http://www.cbd.int/gspc) and Aichi Biodiversity Target 12 (http://www.cbd.int/sp/targets) in Sardinia, and has also built a long-term scientific programme leading to a greater understanding of the autecology and natural regeneration of threatened Sardinian species. This integrated science-based conservation approach is a model that could be applied to other threatened plants to ensure their long-term conservation both in situ and ex situ.

Tiziana Ulian, Efisio Mattana and Hugh W. Pritchard Royal Botanic Gardens, Kew, Ardingly, UK E-mail t.ulian@kew.org

Gianluigi BaCCHETtA Centro Conservazione Biodiversità, Dipartimento di Scienze della Vita e dell'Ambiente, Università degli Studi di Cagliari, Cagliari, Italy

\section{Residents of Mudumalai Tiger Reserve secure funds for resettlement after a 25-year struggle}

It is estimated that nearly 100 million people live within India's forests. Some of these people, living in forest interiors, subsist with minimal access to electricity, education, medical facilities or markets. These forests are the last refuges for many threatened species, including the charismatic tiger and Asian elephant. Voluntary resettlement of families from protected areas can be advantageous for both people and wildlife when conducted in a fair and transparent manner.

The Wildlife Conservation Society India Program (WCS India) supports families who want to resettle from forest interiors, helping resettling or resettled families secure adequate compensation from the government, identifying alternative land, acquiring official identity cards that allow them to apply for various government-sponsored subsidies, obtaining education and medical attention, and integrating them into mainstream economies through livelihood support. WCS India has supported over 1,300 families who have expressed willingness to resettle from within various protected areas in the Malenad conservation landscape of south-west India. 